\title{
Groundwater Quality and its Suitability for Domestic and Agricultural Use in Khanaqin Town, Iraq
}

\author{
Khalid Abdullah and Bhavana N. Umrikar* \\ Department of Geology, University of Pune, Pune-411007, Maharashtra, India.
}

\begin{abstract}
Khanaqin area is drained by an ancient river Al-Wand which is a vital source of water for agricultural activities in the area. In summer months, discharge in Al-Wand River decreases considerably, threatening the agricultural practices and economic situation in Khanaqin. It has been observed that the water levels were high in 1980 s, reaching a dischargelflow of $10 \mathrm{~m}^{3} / \mathrm{s}$ whereas the river flow has been reduced to $>1 \mathrm{~m}^{3} / \mathrm{s}$ or sometimes dry up in summer. As a result the province is suffering from severe scarcity of both drinking- and irrigation water. Ultimately the groundwater dependency is on rise and during last few years the number of bore wells has increased in and around Khanaqin area. In present situation, groundwater is the major source for domestic and agricultural activity in this area. For the present study, the need for groundwater quality analysis was felt and the samples were collected from 16 representative bore wells in the year 2012. These groundwater samples were analyzed for physico-chemical parameters. Based on the limits prescribed by WHO, Iraqi Drinking Water Standards and Bureau of Indian Standard (2003) 25\%, $68.75 \%, 68.75 \%, 43.75 \%, 18.75 \%, 50 \%, 12.5 \%, 50 \%$ and $6.25 \%$ of the samples did not fall under the prescribed safe limits for Total Dissolved Solids, Total Hardness, $\mathrm{Ca}^{+2}, \mathrm{Mg}^{+2}, \mathrm{Na}^{+}$, Alkalinity, $\mathrm{Cl}$ , $\mathrm{SO}_{4}^{-2}$ and $\mathrm{K}^{+}$respectively. Suitability of groundwater for irrigation was evaluated based on various indices. Kelly's Ratio, Permeability Index and Soluble Sodium Percentage analysis shows two, six and two samples falling in unsuitable category respectively, whereas all sixteen samples fall in safe category for Residual Sodium Carbonate index.
\end{abstract}

Keywords: Groundwater quality, drinking, agriculture, suitability indices, Khanaqin, Iraq.

\section{Introduction}

The study based on GRACE data carried out by scientists [1] (The team led by Jay Famiglietti and Kate Voss of the University of California-Irvine (UCI) and Georgetown University with other researchers from NASA's Goddard Space Flight Center and the National Center for Atmospheric Research, used the data acquired by twin gravity-measuring satellites of the Gravity Recovery and Climate Experiment) depicted an alarming rate of decrease in total water storage in the Euphrates and Tigris river basins. The main reasons for this loss of water were listed as increasing demand, over pumping of groundwater, poor management and the impact of the devastating 2007 drought, whose effects are still being felt. Water resources in Kurdistan region comprise the large amount of surface water including the main rivers namely Greater Zab, Lesser Zab, Sirwan and Al-Wand rivers. Al-Wend River flows east - west through the Khanaqin town. The discharge of the river is decreasing at an alarming rate, threatening the agricultural practices and economic situation in Khanaqin. As a result dependency on groundwater is on rise and the integrated approach for water resource management is necessary $[2,3]$. The groundwater quality in the study area is equally important as its quantity $[4,5]$. On this background, the quality of groundwater in Khanaqin town has been evaluated based on different indices to understand the groundwater suitability for drinking and irrigation purposes.

\section{The Study Area}

Khanaqin area is located in the northeast part of Iraq, to the south of the Sulaymaniyah Governorate, near the border of Iran. The Khanaqin town lies between $45^{\circ} 16^{\prime} 00^{\prime \prime}$ and $45^{\circ} 30^{\prime} 00^{\prime \prime}$ East Longitude and between $34^{\circ} 17^{\prime} 00^{\prime \prime}$ and $34^{\circ} 24^{\prime} 00^{\prime \prime}$ North Latitude (Fig. 1). The areal extent is approximately $137 \mathrm{sq} \mathrm{km}$. Khanaqin town has an altitude of approximately $200 \mathrm{~m}$ above mean sea level. 


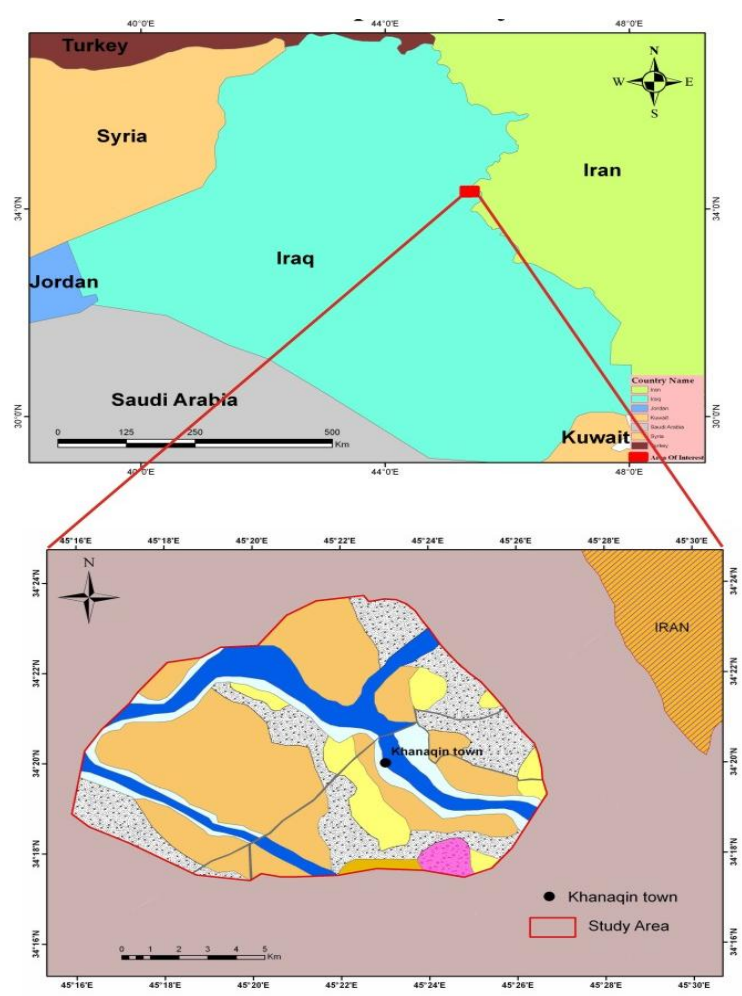

Fig. 1. Location map of Khanaqin town.

The climate of the country is arid to semi- arid continental type. The climate of study area is affected by Mediterranean Climatological System. The climate of north Iraq is very hot-dry in summer and cold in winter, whereas the climate of Khanaqin area is characterized by semi-arid type with hot summer and mild to cold winter. There is a wide variation in distribution of rainfall in the country. Annual rainfall in the northern hills and mountain ranges varies between 300 and $1000 \mathrm{~mm}$ whereas in the extreme south and west it is in the range of 100 to $200 \mathrm{~mm}$. Khanaqin weather station data reveals that the average annual relative humidity is $48.54 \%$. The maximum annual average monthly evaporation is $575.5 \mathrm{~mm}$ in July, while the minimum is $49.9 \mathrm{~mm}$ in January.

\section{Geological Setting}

The study area comprises of Tertiary and Quaternary deposits. Tertiary deposits are divided into Upper Bakhtiary and Lower Bakhtiary formations. The brief description of these formations is given below:

\subsection{Tertiary Deposits}

\subsubsection{Upper Bakhtiari formation (Bai Hassan)}

This formation is characterized by alternate layers of conglomerate, sandstone, clay stone and siltstone. The thickness of this formation ranges between 300 - 1900m [6]. The formation is overlain by alluvial deposits and also covered by fine grained sediment of Quaternary age in some parts. The Bai Hassan formation is originated from the highly folded Zagros zone (Fig. 2).

\subsubsection{Lower Bakhtiari formation (Muqdadiya)}

The Lower Bakhtiari formation comprises of (fining upwards) cycles of gravely sandstone, sandstone and red clay stones [7]. The thickness of the formation in the study area ranges from 1200-1300m [8]. The formation is distributed mostly in the Foothill and Mesopotamian Zone .The Lower Bakhtiari was deposited in fluvial environment in the rapidly subsidence fore deep basin. The Upper and Lower Bakhtiari formations cover the eastern and southern part of the study area.

\subsection{Quaternary Deposits}

The age of these deposits is mostly of Holocene and Pleistocene. It covers a wide area of Khanaqin town and comprises of gravel, sand, clay, loam and conglomerate. The particles size varies from the course gravel to fine silt as well as loam [9]. The intergranular type comprises a good aquifer mostly in the North and Southwest part of the study area. 
The soil in the study area is suitable for agriculture. It has greater thickness near the bank of Al-wand River. The increasing degradation of soils, salinity and the desertification is a common problem in Iraq.

TERTIARY

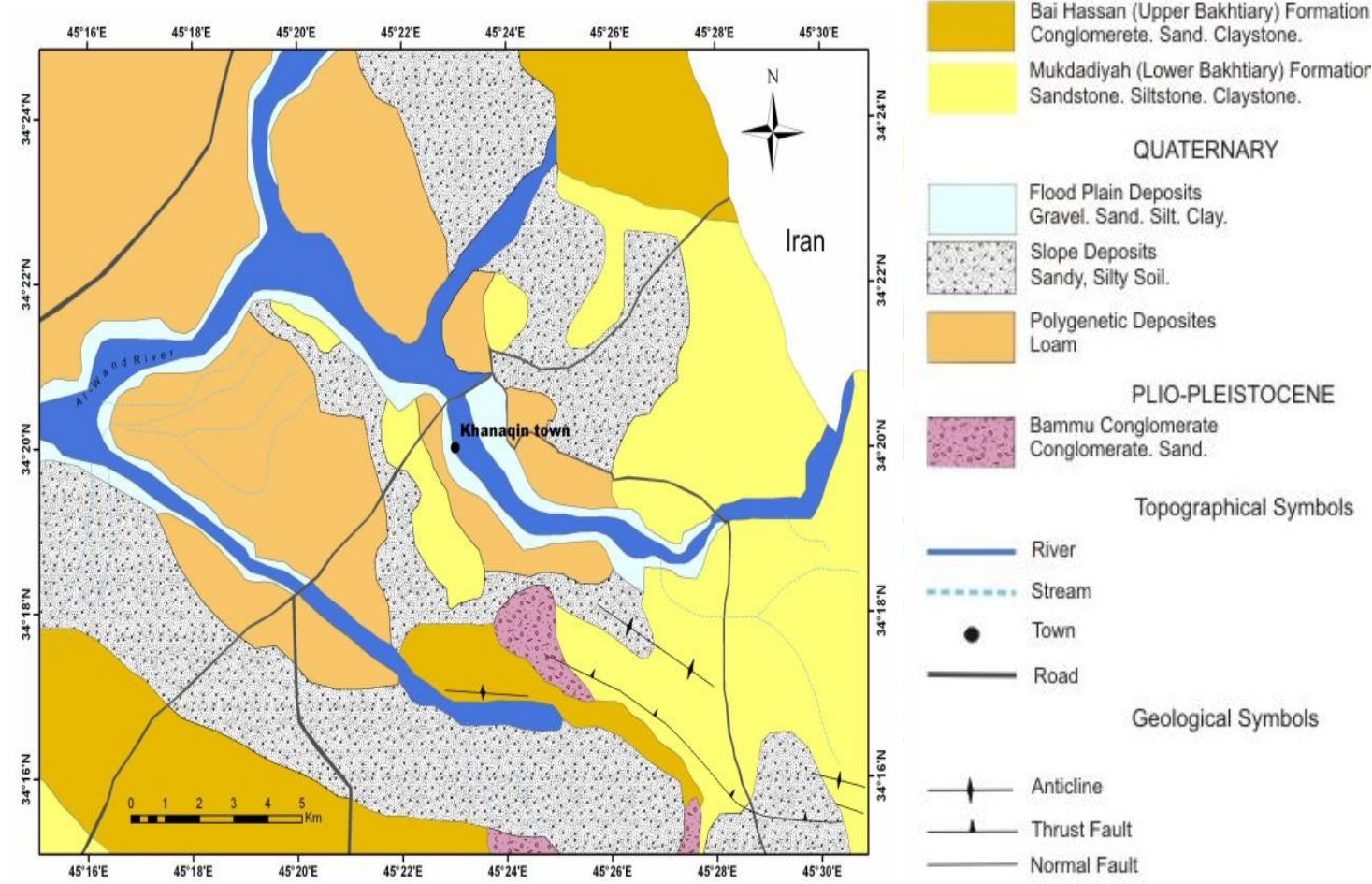

Fig. 2. Geological map of the study area.

\section{Hydrogeology}

Hydrogeological rock units in the Khanaqin area consist of Lower Bakhtiari Formation, Upper Bakhtiari Formation and Quaternary deposits. The hydrogeological characteristics of foothill zone have been studied by Araim and Said [10] and Alsam and Hanna [11]. Local aquifer system or main aquifer system in the Khanaqin area is represented by both Quaternary deposits and Lower Bakhtiari formation [12].

Quaternary deposits consist of conglomerate, gravel, sand, silt and clay. Quaternary aquifers have thickness ranging between 5 and $40 \mathrm{~m}$. These aquifers have high transmissivity and high discharge in wells with low salinity in majority of the wells. Lower Bakhtiari aquifer includes gravel, sandstone and clay stone.

\section{Materials And Methods}

Bore well is the main source for water supply in the area. Total 16 bore wells tapping Lower Bakhtiari, Upper Bakhtiari and Quaternary aquifers were inventoried. According to the lithological profile / section of the wells observed in study area, most of the wells penetrate through Quaternary deposits and few of them have struck the Bakhtiari Formation. The groundwater samples were collected from the bore wells located at the Khanaqin town, as few dug wells exist in this region. The water samples were analyzed in the laboratory of the Directory of Water, Sulaimaniyah Division. The hydrochemical study of groundwater in Khanaqin town includes analysis of major cations - anions [13] and also total alkalinity, Total Hardness (TH), Electrical Conductivity (EC), and hydrogen reactivity $(\mathrm{pH})$.

In the study area the ground elevations were measured by a handheld GPS and depth to static water level was marked by using the electrical sounder in the month of June, 2012. Reduced Level (RL) was calculated by subtracting the static water level from the ground elevation of the well. The location of these wells is shown in Figure 3 and the bore well inventory details are included in Table -1 . The depth of the bore wells in the study area ranges from $36-72 \mathrm{~m}$ and the depth to static water level (S.W.L.) ranges from $8-30 \mathrm{~m}$. The static water level data has been interpolated to generate the water table contours for the dry season (June, 2012) as shown in Figure 4. 


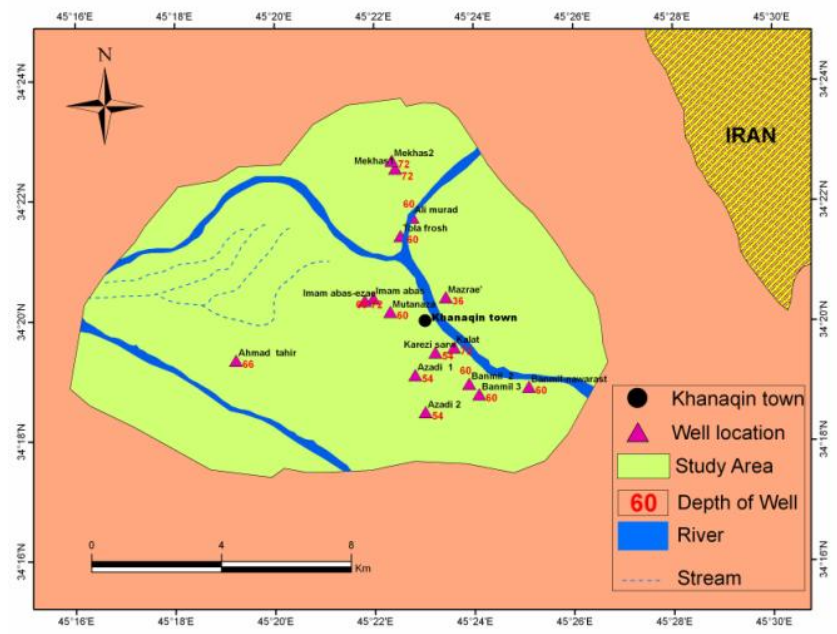

Fig.3. Location map of bore wells inventoried in study area.

Table 1 . The details of bore well inventory.

\begin{tabular}{|l|l|l|l|l|l|l|l|}
\hline $\begin{array}{l}\text { Sr. } \\
\text { No. }\end{array}$ & Location & $\begin{array}{l}\text { Northing } \\
\text { (UTM } \\
\text { coordinate) }\end{array}$ & $\begin{array}{l}\text { Easting } \\
\text { (UTM } \\
\text { coordinate })\end{array}$ & $\begin{array}{l}\text { Elevation } \\
(\mathrm{m})\end{array}$ & $\begin{array}{l}\text { Depth } \\
(\mathrm{m})\end{array}$ & $\begin{array}{l}\text { Static } \\
\text { Water } \\
\text { Level } \\
(\mathrm{m})\end{array}$ & $\begin{array}{l}\text { Discharge } \\
\text { (liters per } \\
\text { second) }\end{array}$ \\
\hline 1 & Banmil 3 & 341846.5 & 452406.1 & 186 & 60 & 14.0 & 6.0 \\
\hline 2 & Upper Kerez & 341928.6 & 452313.3 & 185 & 54 & 10.0 & 6.0 \\
\hline 3 & Banmil Center & 341853.8 & 452460.0 & 186 & 60 & 18.4 & 7.0 \\
\hline 4 & Banmil 2 & 341857.1 & 452353.9 & 187 & 60 & 19.4 & 7.0 \\
\hline 5 & Mazrae & 342023.5 & 452326.0 & 190 & 36 & 17.0 & 5.0 \\
\hline 6 & Imam Abas & 342022.5 & 452159.0 & 188 & 60 & 08.0 & 7.0 \\
\hline 7 & Mutanaza & 342009.2 & 452219.3 & 186 & 60 & 13.0 & 7.0 \\
\hline 8 & Tola frosh & 342125.1 & 452231.7 & 181 & 60 & 10.0 & 8.0 \\
\hline 9 & Imam Abas - ezae & 342020.3 & 452148.4 & 189 & 60 & 30.0 & 3.5 \\
\hline 10 & Kalat & 341933.5 & 452335.9 & 185 & 72 & 25.0 & 5.0 \\
\hline 11 & Mekhas 1 & 342232.5 & 452225.7 & 179 & 72 & 10.4 & 8.0 \\
\hline 12 & Mekhas 2 & 342240.3 & 452221.5 & 177 & 72 & 10.5 & 8.0 \\
\hline 13 & Alimurad & 342143.6 & 452246.2 & 183 & 60 & 10.0 & 8.0 \\
\hline 14 & Azadi 2 & 341828.7 & 452301.1 & 188 & 54 & 15.0 & 7.0 \\
\hline 15 & Azadi 1 & 341906.0 & 452249.0 & 187 & 54 & 20.0 & 8.0 \\
\hline 16 & Ahmad tahir & 341920.9 & 451913.1 & 156 & 66 & 23.0 & 8.0 \\
\hline
\end{tabular}

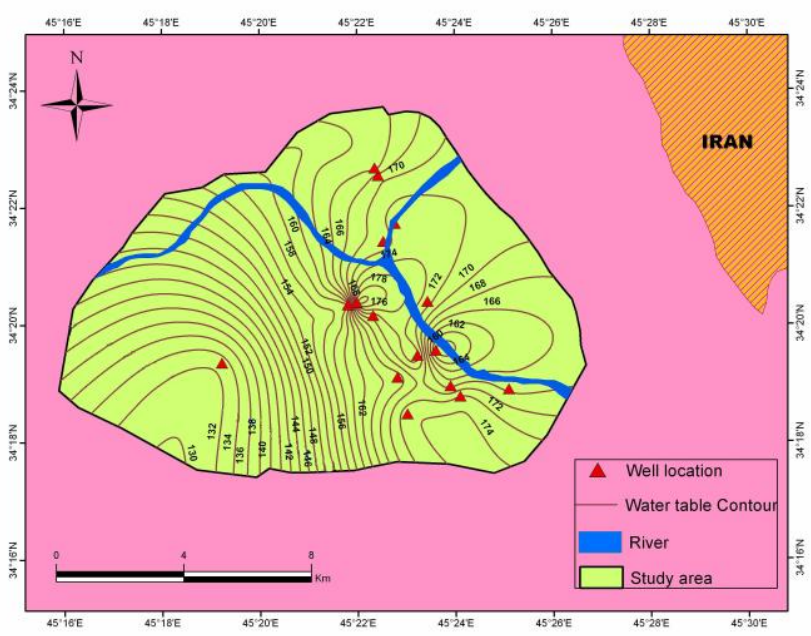

Fig.4. Groundwater table contour map of the study area. 


\section{Results And Discussion}

It is revealed from the groundwater table contour map that the water table contours are closely spaced in the central part of the study area compared to the periphery. The hydraulic head is decreasing towards south and southwest part of the study area. It is depicted from the groundwater table contours that the River has an influent status and hence decreasing discharge in the river will result into decrease in groundwater recharge.

\subsection{Groundwater chemistry}

The $\mathrm{pH}$ values for drinking water as per World Health Organization [14] and Iraqi Drinking Water Standards [15] are falling between 6.5 and 8.5. The $\mathrm{pH}$ value for groundwater samples in study area ranges from $7.12-8.30$ which shows alkaline nature (Table -2). The lowest value of EC is $388 \mu \mathrm{s} / \mathrm{cm}$ in the Mekhas2 bore well located in the north of Khanaqin town, while the highest value of EC $1988 \mu \mathrm{s} / \mathrm{cm}$ is recorded in Banmil Center bore well located toward south of Khanaqin. Most of the groundwater samples show TDS values less than 1000 ppm, except the bore wells in Banmil Center, Imam Abas-Ezae, Ali Murad and Azadi 2 sites that show the TDS content more than $1000 \mathrm{ppm}$. The lowest value of TDS is $194 \mathrm{ppm}$ in Mekhas bore well, while the highest value is $1272 \mathrm{ppm}$ in bore well located at Banmil Center.

Table 2: Physico-chemical data of the bore well groundwater samples.

\begin{tabular}{|c|l|c|c|c|c|c|c|c|c|c|c|}
\hline $\begin{array}{c}\text { Sr. } \\
\text { No. }\end{array}$ & Location & $\mathrm{pH}$ & $\begin{array}{c}\mathrm{EC} \\
\mu \mathrm{s} / \mathrm{cm}\end{array}$ & $\mathrm{TDS}$ & $\begin{array}{c}\mathrm{Ca}^{+2} \\
\mathrm{mg} / \mathrm{l}\end{array}$ & $\begin{array}{c}\mathrm{Mg}^{+2} \\
\mathrm{mg} / 1\end{array}$ & $\begin{array}{c}\mathrm{Na}^{+} \\
\mathrm{mg} / \mathrm{l}\end{array}$ & $\begin{array}{c}\mathrm{K}^{+} \\
\mathrm{mg} / 1\end{array}$ & $\begin{array}{c}\mathrm{HCO}_{3}^{-} \\
\mathrm{mg} / \mathrm{l}\end{array}$ & $\begin{array}{c}\mathrm{SO}_{4}^{-2} \\
\mathrm{mg} / 1\end{array}$ & $\begin{array}{c}\mathrm{Cl}^{-} \\
\mathrm{mg} / 1\end{array}$ \\
\hline 1 & Banmil 3 & 7.7 & 1518 & 972 & 216 & 188.6 & 220 & 1.29 & 255 & 640 & 88 \\
\hline 2 & Upper karez & 7.9 & 1518 & 974 & 400 & 339.9 & 356 & 3.73 & 325 & 1080 & 342 \\
\hline 3 & Banmil-Center & 7.6 & 1988 & 1272 & 264 & 225.15 & 127 & 1.38 & 325 & 665 & 121 \\
\hline 4 & Banmil 2 & 8.2 & 1505 & 963 & 240 & 197.18 & 83 & 1.38 & 200 & 675 & 92 \\
\hline 5 & Mazrae' & 8.1 & 1433 & 910.7 & 236 & 2.4 & 69.7 & 3.07 & 290 & 358.4 & 83 \\
\hline 6 & Imam abas & 8.1 & 1251 & 800.6 & 188 & 36.4 & 65.6 & 3.1 & 310 & 324.8 & 83 \\
\hline 7 & Mutanaza & 8.0 & 1262 & 807.6 & 184 & 47.5 & 67.6 & 3.45 & 316 & 259.2 & 84 \\
\hline 8 & Tola frosh & 7.6 & 1135 & 726.4 & 144 & 116.3 & 40.8 & 1.85 & 325 & 187 & 54 \\
\hline 9 & Imam Abas- & 7.8 & 1931 & 1235 & 336 & 227.4 & 65.6 & 1.85 & 150 & 132 & 75 \\
\hline 10 & Kaalat & 8.3 & 1940 & 988 & 140 & 46 & 47 & 2.37 & 160 & 162 & 68 \\
\hline 11 & Mekhas 1 & 7.4 & 1062 & 205 & 66.1 & 25.4 & 56 & 1.3 & 175 & 53 & 39 \\
\hline 12 & Mekhas 2 & 7.5 & 388 & 194 & 48 & 36 & 21.2 & 1.42 & 210 & 62.31 & 32 \\
\hline 13 & Ali murad & 8.2 & 945 & 1173 & 2.5 & 1.8 & 10.3 & 2.15 & 25 & 9 & 3.8 \\
\hline 14 & Azadi 2 & 7.1 & 1760 & 1186 & 110 & 65 & 264 & 12 & 88 & 499 & 380 \\
\hline 15 & Azadi 1 & 7.4 & 1321 & 670 & 75.1 & 25 & 81 & 2.02 & 92 & 200 & 117 \\
\hline 16 & Ahmad Tahir & 7.1 & 1075 & 713 & 53 & 28 & 148 & 0.6 & 68 & 230 & 190 \\
\hline
\end{tabular}

\subsection{Hydrochemical Facies}

Piper plot has been used to infer the hydrochemical facies of groundwater. It has been depicted from the Piper Trilinear Diagram [16] that most of the groundwater samples in study area fall under the $\mathrm{Ca}^{2+}+\mathrm{Mg}^{2+}-$ $\mathrm{Cl}^{-}+\mathrm{SO}_{4}{ }^{2-}$ groundwater facies (Fig. 5). The facies falls within the alkaline earth water type.

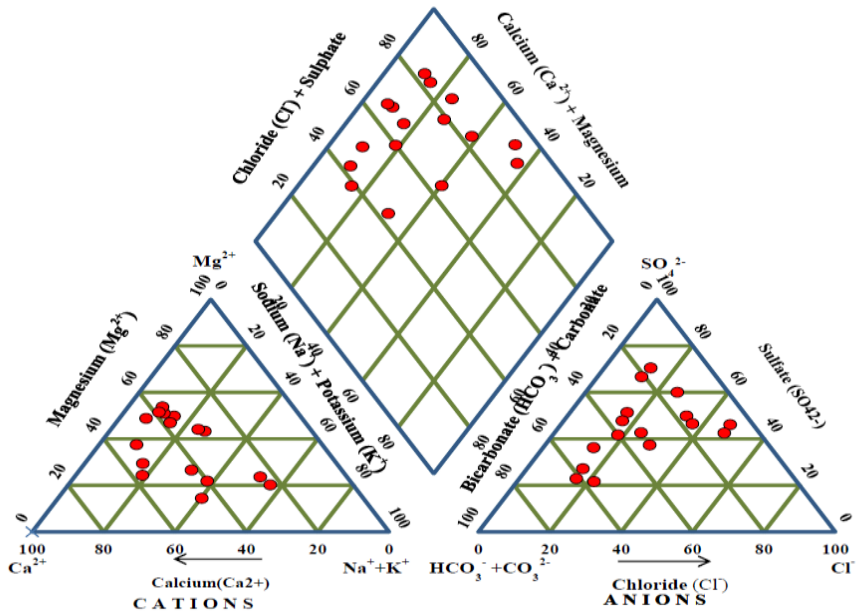

Fig.5. Piper's trilinear diagram showing hydrochemical facies for the groundwater samples. 


\subsection{Groundwater quality for drinking purposes}

Based on the limits prescribed by WHO, Iraqi Drinking Water Standard and Bureau of Indian Standard $[14,15,17] 25 \%, 68.75 \%, 68.75 \%, 43.75 \%, 18.75 \%, 50 \%, 12.5 \%, 50 \%$ and $6.25 \%$ of the samples did not fall under the prescribed safe limits for TDS, TH, $\mathrm{Ca}^{+2}, \mathrm{Mg}^{+2}, \mathrm{Na}^{+}$, Alkalinity, $\mathrm{Cl}^{-}, \mathrm{SO}_{4}^{-2}$ and $\mathrm{K}^{+}$respectively (Table $3)$.

Table 3. Standards for drinking water and \%age of samples exceeding the standard limit.

\begin{tabular}{|c|c|c|}
\hline \multicolumn{2}{|c|}{ Drinking Purpose } \\
\hline Chemical Constituents & $\begin{array}{c}{ }^{1} \text { WHO (2006) }{ }^{2} \text { Iraqi Drinking Water Standard (1998), } \\
\text { Indian Standards (1993), }\end{array}$ & $\begin{array}{c}\text { Samples (\%) exceed } \\
\text { the safety limits }\end{array}$ \\
\hline${ }^{1} \mathrm{pH}$ & $6.5-8.5$ & - \\
\hline${ }^{1} \mathrm{TDS}$ & 1000 & 25.00 \\
\hline${ }^{2} \mathrm{TH}$ & 500 & 68.75 \\
\hline${ }^{1} \mathrm{Ca}^{2+}$ & 75 & 68.75 \\
\hline${ }^{2} \mathrm{Mg}^{2+}$ & 50 & 43.75 \\
\hline${ }^{1} \mathrm{Na}^{+}$ & 200 & 18.75 \\
\hline${ }^{3} \mathrm{Alkalinity}^{1}$ & 200 & 50.00 \\
\hline${ }^{1} \mathrm{Cl}^{-}$ & 250 & 12.50 \\
\hline${ }^{1} \mathrm{SO}_{4}{ }^{2-}$ & 250 & 50.00 \\
\hline${ }^{1} \mathrm{~K}^{+}$ & 12 & 06.25 \\
\hline
\end{tabular}

6.4 Suitability of groundwater for Agriculture Purpose

All the values are in $\mathrm{mg} / \mathrm{l}$ except $\mathrm{pH})$.

6.4.1 Salinity Hazard Diagram: The US Salinity Laboratory Staff based on SAR and Electrical Conductivity values of waters proposed a diagram to ascertain the suitability of waters for agricultural purpose (Fig. 6). In this diagram, electrical conductivity values are plotted on $\mathrm{x}$-axis and SAR on y-axis.

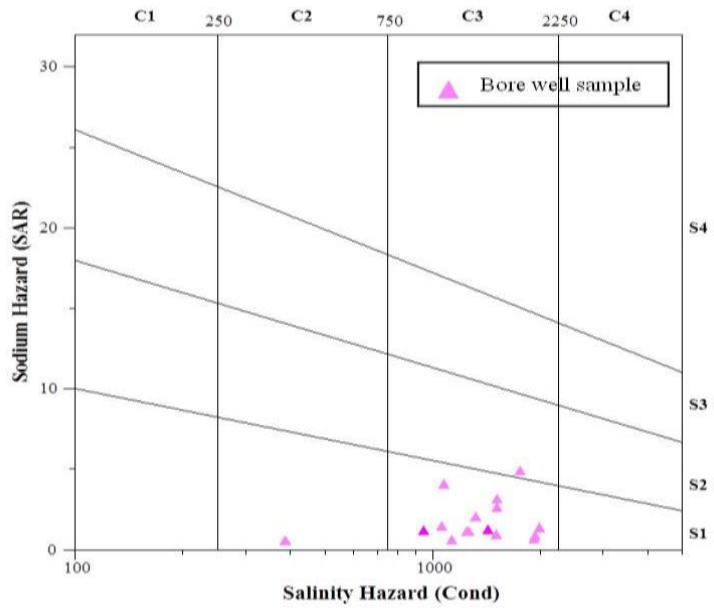

Fig. 6. Salinity classification of groundwater for irrigation (US salinity Laboratory, 1954).

6.4.2 Sodium Absorption Ratio: According to USDA [18] the groundwater having SAR values less than 10 are considered to be excellent, 10 to 18 as good, 18 to 26 as doubtful and above 26 are unsuitable for irrigation. Table 4 shows the percentage of samples falling in good and moderate category. The values for SAR, PI, KR, SSP and RSC indices are included in Table 5.

Table 4. U.S. Salinity classes and the samples (\%) falling in various categories.

\begin{tabular}{|c|c|c|c|}
\hline \multicolumn{4}{|c|}{ Irrigation Purpose } \\
\hline Figure & Classification & Samples (\%) & Water Quality Type \\
\hline \multirow{3}{*}{ 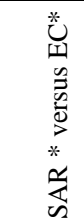 } & $\mathrm{S} 1 \mathrm{C} 2$ & 6.25 & Good \\
\hline & S1 C3 & 87.5 & Moderate \\
\hline & $\mathrm{S} 2 \mathrm{C} 3$ & 6.25 & Moderate \\
\hline
\end{tabular}


Table 5. Values of SAR, PI, KR, SSP and RSC in groundwater samples.

\begin{tabular}{|c|l|c|c|c|c|c|c|}
\hline Well No* & \multicolumn{1}{|c|}{ Location } & $\% \mathrm{Na}$ & SAR & PI & KR & SSP & RSC \\
\hline 1 & Banmil 3 & 26.73 & 2.64 & 32.36 & 0.36 & 26.66 & -22.12 \\
\hline 2 & Upper karez & 24.51 & 3.16 & 28.05 & 0.32 & 24.41 & -42.61 \\
\hline 3 & Banmil-Center & 14.91 & 1.39 & 21.03 & 0.17 & 14.83 & -26.37 \\
\hline 4 & Banmil 2 & 11.45 & 0.96 & 17.04 & 0.13 & 11.35 & -24.92 \\
\hline 5 & Mazrae' & 9.66 & 0.79 & 16.23 & 0.10 & 9.44 & -24.31 \\
\hline 6 & Imam Abas & 40.27 & 3.32 & 50.96 & 0.67 & 40.04 & -7.29 \\
\hline 7 & Mutanaza & 18.74 & 1.15 & 32.50 & 0.22 & 18.29 & -7.91 \\
\hline 8 & Tola frosh & 9.78 & 0.61 & 22.01 & 0.11 & 9.55 & -11.43 \\
\hline 9 & Imam Abas-ezae & 7.55 & 0.68 & 11.52 & 0.08 & 7.43 & -33.03 \\
\hline 10 & Kalat & 16.31 & 0.88 & 28.54 & 0.19 & 15.91 & -8.16 \\
\hline 11 & Mekhas1 & 31.32 & 1.48 & 52.75 & 0.45 & 31.03 & -2.51 \\
\hline 12 & Mekhas1 & 15.16 & 0.56 & 44.25 & 0.17 & 14.67 & -1.91 \\
\hline 13 & Ali Murad & 10.51 & 0.31 & 22.79 & 0.10 & 9.47 & -3.90 \\
\hline 14 & Azadi 2 & 52.10 & 4.93 & 56.81 & 1.06 & 51.43 & -9.40 \\
\hline 15 & Azadi 1 & 38.11 & 2.07 & 50.95 & 0.61 & 37.77 & -4.29 \\
\hline 16 & Ahmad Tahir & 56.61 & 4.09 & 65.82 & 1.30 & 56.55 & -3.83 \\
\hline
\end{tabular}

6.4.3 Permeability Index (PI): Doneen [19] and WHO [op cit] has mentioned the criterion for assessing the suitability of groundwater for irrigation based on this index, where the concentrations are in meq/l. The PI values above 75 are indicative of excellent quality of groundwater for irrigation; between 25 and 75 good quality and the values below 25 reflect unsuitability of groundwater for agriculture purpose (Table 6).

Table 6. Number of samples falling in excellent, good and unsuitable category

\begin{tabular}{|c|c|c|c|}
\hline \multirow{2}{*}{$\begin{array}{c}\text { Groundwater } \\
\text { samples }\end{array}$} & \multicolumn{3}{|c|}{ PI } \\
\cline { 2 - 4 } & Excellent & $25-75$ & $<25$ \\
\hline No. of samples & 1 & Good & Unsuitable \\
& & 9 & 6 \\
& & & \\
\hline
\end{tabular}

6.4.4 Kelly's Ratio (KR): Sodium measured against calcium and magnesium was considered by Kelly [20] to calculate this parameter, in order to evaluate the suitability of groundwater for agricultural purpose. There are 14 samples falling in excellent category (Table 7).

Table 7. Number of samples showing excellent and unsuitable category.

\begin{tabular}{|c|c|c|}
\hline \multirow{2}{*}{ Groundwater samples } & \multicolumn{2}{|c|}{ KR } \\
\cline { 2 - 3 } & Excellent & Unsuitable \\
\cline { 2 - 3 } & & 2 \\
\hline \multirow{2}{*}{ No. of samples } & 14 & 2 \\
\hline
\end{tabular}


6.4.5 Soluble Sodium Percentage (SSP): The values of SSP, if less than 50, indicate good quality of groundwater whereas above 50 unsuitability of water for agricultural purpose (Table 8).

Table 8. Soluble sodium percentage based classification of groundwater samples.

\begin{tabular}{|l|c|c|}
\hline \multirow{2}{*}{ Domain } & \multicolumn{2}{|c|}{ SSP } \\
\cline { 2 - 3 } & SSP $<50$ & SSP $>50$ \\
\cline { 2 - 3 } & Good & Unsuitable \\
\hline No. of samples & 14 & 2 \\
& & \\
\hline
\end{tabular}

6.4.6 Residual Sodium Carbonate (RSC): RSC has been calculated to determine the detrimental effect of carbonate and bi-carbonate on the quality of groundwater for agricultural purpose [21]. When the RSC values are less than $1.25 \mathrm{epm}$, the groundwater is considered to be safe for irrigation. If the value is between $1.25 \mathrm{epm}$ and $2.5 \mathrm{epm}$ then the water is marginally suitable, while the value above $2.5 \mathrm{epm}$ indicate the groundwater unsuitability for irrigation. All the groundwater samples are falling in safe category (Table 9).

Table 9. Residual Sodium Carbonate based classification of water samples.

\begin{tabular}{|l|c|c|c|}
\hline \multirow{2}{*}{ Domain } & \multicolumn{3}{|c|}{ RSC } \\
\cline { 2 - 4 } & $<1.25$ & $1.25-2.5$ & $>2.5$ \\
\cline { 2 - 4 } & Safe & Marginal & Unsuitable \\
\hline No. of samples & 16 & - & - \\
& & & \\
\hline
\end{tabular}

\subsection{Pearson Correlation Matrix}

A high correlation coefficient (near +1 or -1 ) shows a good relationship between two variables and a correlation value near zero means there is no considerable relationship between them. More precisely, when $r$ has a value between 0.5 and 0.7 moderate correlation is said to exist whereas the parameters showing $r>0.7$ are considered to be strongly correlated.

In the present study, there is a perfect correlation between EC and TDS which indicates EC is a measure of total dissolved solids in the groundwater. TDS has a medium positive correlation with $\mathrm{Ca}^{+2}$ suggesting that the aquifer chemistry is mainly controlled by calcium. The matrix shows fairly high correlation of $\mathrm{Ca}^{+2}, \mathrm{Mg}^{+2}, \mathrm{Na}^{+}$with $\mathrm{SO}_{4}^{-2}$, also high correlations between $\mathrm{SO}_{4}^{-2}-\mathrm{Mg}^{+2}, \mathrm{SO}_{4}^{-2}-\mathrm{Ca}^{+2}$ and $\mathrm{Ca}^{+2}-\mathrm{Mg}^{+2}$ were observed (Table 10). 
Table 10. Pearson Correlation Matrix Table

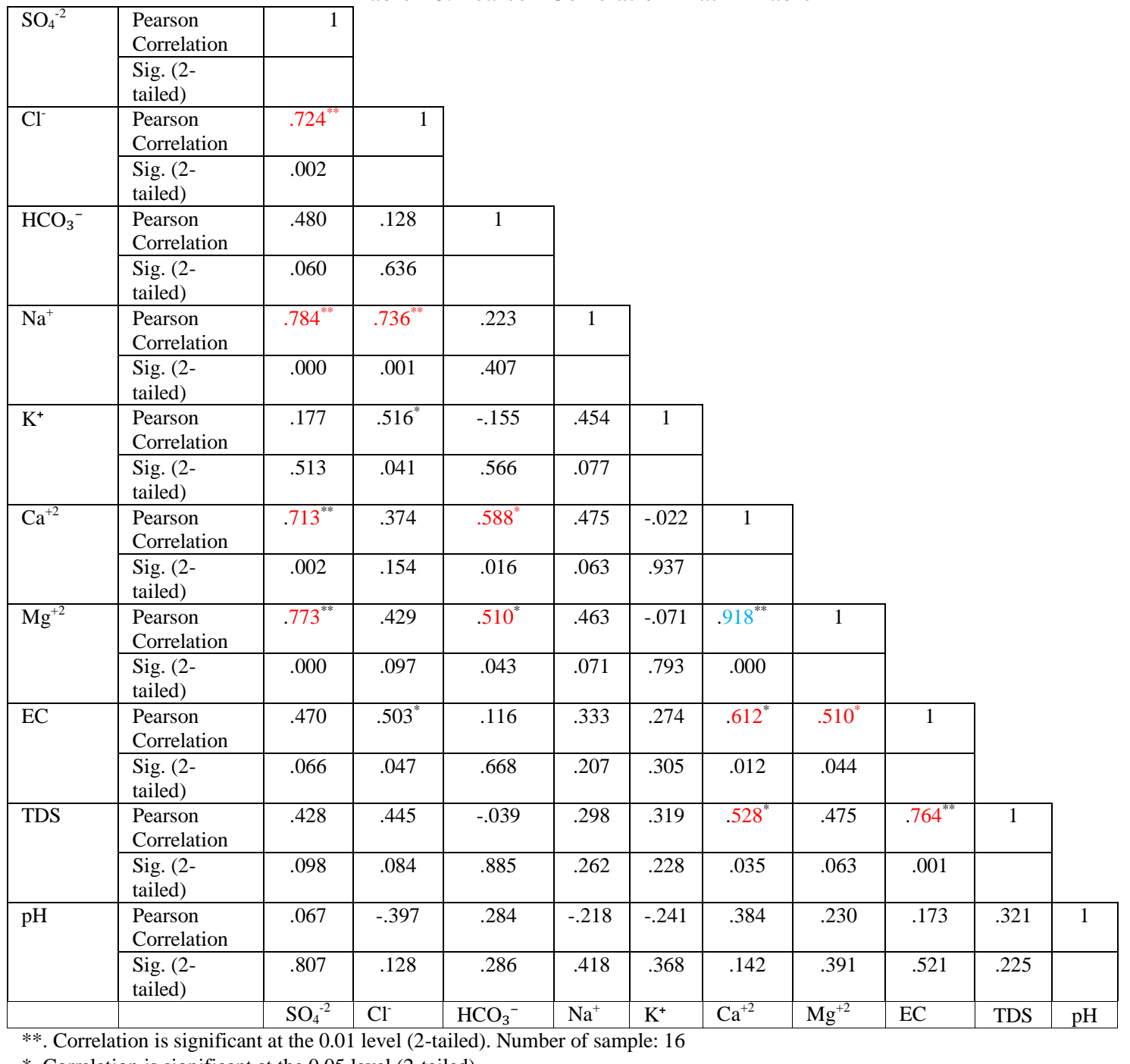

*. Correlation is significant at the 0.05 level (2-tailed).

\section{Conclusion}

1- Based on the limits prescribed by WHO, Iraqi Drinking Water Standard and Bureau of Indian Standard the results revealed that $25 \%, 68.75 \%, 68.75 \%, 43.75 \%, 18.75 \%, 50 \%, 12.5 \%, 50 \%$ and $6.25 \%$ of the bore well samples did not fall under the prescribed safe limits for Total Dissolved Solids, Total Hardness, $\mathrm{Ca}^{+2}$, $\mathrm{Mg}^{+2}, \mathrm{Na}^{+}$, Alkalinity, $\mathrm{Cl}^{-}, \mathrm{SO}_{4}^{-2}$ and $\mathrm{K}^{+}$respectively.

2- Generally all bore wells are used for drinking purpose, because the ratio of each ionic concentration is not exceeding the Iraqi Drinking Water Standard (IDWS).

3- According to chemical analysis of the groundwater samples in Mekhas area, and Ahmad Tahir area located in the southwest part of the study area, both the sub-basins are showing better quality for drinking purpose.

4- $\quad$ The $\mathrm{pH}$ of some groundwater samples is greater than 8 indicates the increasing calcium carbonate, which is contributed to clay minerals from Quaternary deposits and Lower Bakhtiari formation.

5- The salinity in some bore wells is high, which generally relates to clay minerals and high evaporation rates.

6- Kelly's Ratio, Permeability Index and Soluble Sodium Percentage analysis shows two, six and two samples falling in unsuitable category respectively, whereas all sixteen samples fall in safe category for Residual Sodium Carbonate index.

\section{References}

[1]. Famiglietti J. See more at: http://www.setyoufreenews.com/2013/03/13/tigris-and-euphrates-rivers-losing-water-reserves-at-a-rapidpace/\#sthash.iKgeMak3.dpuf. 
[2]. Al-Manmi DA. Water Resources management in Rania Area, Sulaimaniyah, NE-Iraq. Unpublished P.hD. Thesis, College of Science, University of Baghdad. 2008; 225. Heshmati A. Integrated Water Resource Management in the Kurdistan Region (Water Resource Planning, Development and Management). Nova Science Publishers, Inc., 2013; ISBN-13: 978-1607412953, 225.

[3]. Lawa FA, Kareem KH, Ali SS. Hydrogeological study of Sulaimaniyah and part of Kirkuk areas, NE Iraq.Part two: Bazian-Sangaw Basin, Surdash-Koya asin, Qaradagh-Kalar Basin. Report, FAO GWU documentation Fund, Erbil; 2002.

[4]. Nabi AQ. Limnological and bacteriological studies on some wells within Hawler city, Kurdistan region, Iraq. M.Sc. Thesis, Univ. of Salahaddin, Hawler; 2005.

[5]. Al-Jibori H. Hydrogeological map of Khanaqin, sheet (NI, 38-7), state company of geological survey and mining -Iraq; 2006

[6]. Buday.T, Jassim SZ. The regional geology of Iraq, vol.2:Tectonism., Magmatism and metamorphism. Publication of GEOSURV, Baghdad, 1987; 352

[7]. Taha MA. The Displacement Criteria in Fibrous Crystalline Gypsum Veins in Hamrin South Anticline East of Iraq. J. of Basra Researches (Sciences); 2010; 36 (4): 29-41.

[8]. Buday T. The Regional Geology of Iraq, Vol. I. Stratigraphy and Paleogeography. I.I.M. Kassab and S.Z.Jassim (eds). SOM, Baghdad, Dar El Kutib Publ. House, Univ. of Mosul., 1980; 445.

[9]. Araim HI, Said H. Groundwater regional study in the adhaim river basin with emphasis on the pain area. Manuscript report, Geosurv, Baghdad, 1980.

[10]. Alsam SI, Hanna F. Evoluation of groundwater resources in Khazir-Gomel basin. Manuscript report, Geosurv, Baghdad.Ameen, M.S. (1992) Effect of basement tectonics on hydrocarbon generation, migration, and accumulation in northern Iraq. AAPG; 1983; 76(3): $356-370$

[11]. Shawkat A. Hydrogeology of Khanaqin area. Ministry of water resource. 2005; 127.

[12]. American Public Health Association (A.P.H.A). Standard Methods For The Examination of Water and Waste Water, 16th ed. A.P.H.A., 1015 Eighteenth street NW, Washington, DC. 1989; 36.

[13]. WHO. Guidelines to drinking water quality. World Health Organization, Geneva; 1996; $2: 989$.

[14]. Iraq Drinking Water Standards. First update-drinking-water, IQS 417/2001, ICS: 13.060.20, Council of Ministers - Central Agency for Meteorology and Quality Control; 2001.

[15]. Piper AM. A graphical procedure in the geochemical interpretation of water analysis. Transactions American Geophysical Union; 1944; 25: 914-928.

[16]. BIS. Bureau of Indian Standards Specification for drinking water. IS: 10500:91. Revised 2003, Bureau of Indian Standards, New Delhi. 2003.

[17]. U.S. Department of Agriculture. Diagnosis and Improvement of Saline and Alkali Soils, U.S. Salinity Laboratory Staff. Handbook, Government Printing Office, Washington D.C.; 1954; 60.

[18]. Doneen LD. Water quality for agriculture. Department of Irrigation, University of California, Davis. $1964 ; 48$.

[19]. Kelly WP. Adsorbed sodium cation exchange capacity and percentage sodium sorption in alkali soils. Science. 1957; 84: $473-477$.

[20]. Eaton FM. Significance of carbonate in irrigation waters. Soil Science, 1950; 69: 123-133. 